\title{
Importance of Cultural Competence Development in Training Pre-service Teachers of Foreign Languages
}

\author{
Gerda Mazlaveckienè \\ Lecturer and PhD student at Lithuanian University of Educational Sciences \\ gerda.mazlaveckiene@leu.It
}

\author{
DOI:10.5901/mjss.2014.v5n19p62
}

\begin{abstract}
Teaching and learning a foreign language is incomplete and inaccurate without the study of culture. For learners, language studies seem senseless if they know nothing about the people who speak the target language or the country in which the target language is spoken. By failing to draw students' attention to the cultural elements and to discuss their implications, teachers allow misconceptions to develop in students' minds. Therefore, realizing it or not, language teachers cannot avoid conveying impressions of another culture: language cannot be separated from the culture in which it is embedded. For both scholars and teachers, cultural competence, i.e. the knowledge of the conventions, customs and beliefs of another country, skills and abilities to interpret and relate one's native and foreign cultures, as well as provide critical judgment, is indisputably an integral part of foreign language teaching and learning, and many teachers see it as their goal to incorporate the cultural dimension into the foreign language curriculum. Hence, the article focuses on the importance of developing the cultural competence of pre-service teachers of foreign languages. With this aim, a research was conducted in spring and autumn 2013 and involved a sample of 504 students of foreign languages of five Lithuanian universities: Lithuanian University of Educational Sciences, Vilnius University, Šiauliai University, Vytautas Magnus University and Klaipeda University. The questionnaire consisted of several sections, which aimed at identifying the current level of the cultural competence of pre-service teachers of foreign languages, namely their knowledge about culture in general and country-specific culture facts, emotions evoked by different cultural events, abilities and experience of functioning in different cultural environments, as well as other factors determining their cultural competence.
\end{abstract}

Key words: culture, cultural competence, foreign language teaching and learning, pre-service teachers of foreign languages, teacher training, native language/culture, target languageculture.

\section{Introduction}

The dialectical connection between language and culture has always been a concern of both scholars and educators. In the course of time, the pendulum of the opinions of foreign language researchers and educators has swung either against or in favour of the cultural dimension in foreign language teaching and learning. For example, already in the first decades of the 20th century researchers discussed the importance and possibilities of incorporating cultural components into L2 curriculum. In 1904, in his book How to Teach Foreign Languages, Jespersen stated that the highest purpose in the teaching of languages may perhaps be said to be the access to the best thoughts and institutions of a foreign nation in the widest sense of the world' (cited in Genc \& Bada, 2005, p. 73). Yet, the most outstanding linguists concerned with the issues of language and culture are Sapir (1962) and Whorf (1956). The focus of their theory is that the world is perceived by human beings in terms of categories found in their mother tongues. However, what is found in one language may not be found in another language due to cultural differences.

The emergence of Communicative Language Teaching (CLT) in the late 70s of the last century notes a critical shift in teaching/learning culture: it marks the paradigm shift from the approach based on form and structure to a plurality of approaches focusing on the learners' communicative needs, as well as expression, interpretation and negotiation of meanings and looks (Savignon, 2002). However, the need for teaching culture in language classes reaches its climax only in the 1990s in the writings of scholars such as Byram $(1994,2002)$ and Kramsch $(2000)$. People involved in foreign language teaching/learning have again begun to understand the intertwined relations between language and culture. It is maintained that without the study of culture, teaching/learning a foreign language is incomplete and inaccurate. For the learners, language studies seem senseless if they know nothing about the people who speak the target language or the country in which the target language is spoken (Genc \& Bada, 2005). As Qu (2010) notes, by failing to draw students' attention to the cultural elements and to discuss their implications, teachers allow misconceptions to develop in students' minds. Therefore, realizing it or not, language teachers cannot avoid conveying impressions of another culture: language 
cannot be separated from the culture in which it is embedded. For both scholars and teachers, cultural competence, i.e. the knowledge of the conventions, customs and beliefs of another country, skills and abilities to interpret and relate one's native and foreign cultures, as well as provide critical judgement, is indisputably an integral part of foreign language teaching/learning, and many teachers see it as their goal to incorporate culture aspects into the foreign language curriculum.

The highlighted approach to developing cultural competence through foreign language teaching/learning sets new objectives to education, including foreign language teaching/learning. One of the key goals of the Council of Europe for teaching/learning foreign languages is to 'achieve a wider and deeper understanding of the way of life and forms of thought of other peoples and of their cultural heritage' (CERFL, 2001, p. 6), which is implemented through the development of cultural competence of pre-service and in-service teachers of foreign languages. The significance of cultural education is also highlighted in Lithuanian documents on education. The Law on Education of the Republic of Lithuania (2011) provides for 'conveying national and ethnic fundamentals, and traditions and values of European and world humanist culture, ensuring conditions for a person's mature national identity, moral, aesthetic and academic culture, developing own world outlook, as well as guaranteeing continuity of the national culture, preserving its identity and continuous development of values, cherishing the openness and dialogic nature of the state' as well as 'providing possibilities for a person to acquire fundamentals of democracy-oriented civil and political culture, developing abilities and experience essential for a person to develop as a competent citizen of Lithuania and a member of the European and global multi-cultural community' (2011, $p$. 15-16).

The changes in foreign language teaching/learning pose challenges for teacher training. A teacher, especially the one of foreign languages, becomes 'a teacher of culture' and is expected to assume new tasks: his/her attention is focused not on mere transfer of knowledge, but rather on the development of new attitudes, skills and critical awareness. In other words, the new task of a teacher of a foreign language is to develop students' competence, which would encourage them to link and compare the cultural values, attitudes and behaviour with the target culture as reflected in the language. The topicality of cultural education is highlighted in the National Description of Teacher Competences of Lithuania, where cultural competence is defined as "knowledge, skills, abilities, value-based provisions and other personal qualities determining human activity in specific culture(s)' $(2007$, p. 1). Therefore, the aim of the current research is to disclose the ways of expression of the cultural competence of pre-service teachers of foreign languages and opportunities of its development at the university.

\section{Research Methods}

Theoretical methods: analysis of scientific literature and strategic documents on training teachers of foreign languages and the conception of cultural competence;

Empirical methods: a survey, including open-ended and closed-ended questions, which help to reveal the attitude of pre-service teachers of foreign languages to cultural competence and opportunities of its development through target language studies at the university.

Statistical methods: the research data are processed using Statistical Package for Social Sciences (SPSS) 17.0.

\section{Research Sample}

The research sample involves 504 students of foreign languages of five largest Lithuanian universities: Lithuanian University of Educational Sciences, Vilnius University, Šiauliai University, Vytautas Magnus University and Klaipèda University. The respondents are to acquire a qualification of a teacher of the English, German, French, Polish or Russian language upon the completion of studies. The total sample includes $83.5 \%$ of female students $(n=421)$ and $16.5 \%$ of male students $(n=81)$. Such a big discrepancy occurs due to the study preferences of the Lithuanian youth: languages are mostly preferred by females rather than by males.

According to the distribution of the year of studies, the sample splits fairly equally: $30.8 \%$ of first-year students ( $n=155)$, $25.6 \%$ of second-year students ( $n=129), 26.8 \%$ of third-year students $(n=135)$ and $16.9 \%$ of fourth-year students $(n=85)$. The number of fourth-year students is smaller than the remaining three groups of the sample, which is conditioned by a larger number of drop-outs incurred in the previous three years of studies.

The distribution of respondents in terms of the institution they study at is as follows: $44.4 \%$ study at Lithuanian University of Educational Sciences ( $n=224), 14.5 \%$ study at Vilnius University $(n=73), 19.0 \%$ study at Vytautas Magnus University 
$(n=96), 14.1 \%$ study at Šiauliai University $(n=71)$ and $7.9 \%$ at Klaipéda University. The largest number of LUES respondents accounts for the fact that it is the largest teacher training institution in Lithuania: nearly all the study programmes offered by the university grant a teacher's qualification. The situation is different in the remaining four universities, which offer a considerably smaller number of study programmes granting a teacher's qualification. It is noteworthy that as far as $51 \%$ of respondents do not intend to work as teachers $(n=257)$ after graduation.

\section{Theoretical Background of the Research}

Scientific literature and education documents define the term competence in a number of different ways. Generally speaking, competence is defined as a combination of knowledge, skills and attitudes appropriate to the context (Recommendation of the European Parliament and of the Council on Key Competences for Life-long Learning, 2006), which are complemented by values one holds because of one's belonging to a number of social groups (Byram, Gribkova, Starkey, 2002).

The foundation of cultural competence is in the attitudes, which include curiosity and openness, readiness to suspend disbelief about other cultures and belief about one's own. This means that a learner should not assume that his/her values, beliefs and behaviour are the only possible and naturally correct. They have to be able to see how they might look from an outsider's perspective, i.e. they have to develop an ability to 'decentre'.

Another crucial factor is knowledge and awareness, primarily not about a specific culture, but rather knowledge on how social groups and identities function and what is involved in (inter)cultural interaction. Cultural awareness comprises information about how people behave both linguistically and extra-linguistically in common everyday situations, e.g. greetings, excusing oneself, leave taking, forms of address, asking for or giving directions, expressing respect, thanking, inquiry, giving or receiving compliments, etc., which are complemented by para-linguistic behaviour, such as gestures, touching, eye contact and the like.

Skills are just as important as attitudes and knowledge. Byram (2002) distinguishes between the skills of interpreting and relating, which refer to the ability to interpret a document or event from another culture, to explain it and relate it to documents or events from one's own; and skills of discovery and interaction, which cover the ability to acquire new knowledge of a culture and cultural practices and the ability to operate knowledge, attitudes and skills under the constraints of real-time communication and interaction.

Finally, however open towards, curious about and tolerant of other people's beliefs, values and behaviours learners are, their own beliefs, values and behaviours are deeply embedded and can create reaction and rejection. Therefore, intercultural mediators need some critical awareness or literacy: an ability to evaluate critically and on the basis of explicit criteria, perspectives, practices and products of one's own and other cultures (Bauman, 2007, p. 35). Australian educationalist M. Pegrum (2008) stresses the significance of critical intercultural literacy, which involves abilities and skills 'to read' cultural information in different information sources, critically assess it in terms of personal knowledge and experience, and at the same time critically evaluate old knowledge in the light of new experience. Such skills are essential for a contemporary student, as they contribute to one's integration into the global world.

In this regard, a four-dimensional model of cultural competence of pre-service teachers of foreign languages has been designed, which includes the following components:

knowledge and awareness of cultural phenomena, which is characterized by the amplitude (the quantity of provided arguments) and profoundness (identification of fundamental properties) of knowledge and awareness;

the sphere of knowledge and awareness is closely linked to the attitude towards culture-specific phenomena in the country of native and target language. It is assumed that this component helps to reveal a respondent's emotional reaction to and evaluation of a cultural object (phenomenon);

involvement in cultural activity, which is characterized by a person's readiness and ability to act in different culture-specific situations;

cultural literacy and experience, which helps to reveal and assess a pre-service teacher's reflection on own cultural and linguistic expression in different cultural contexts. 


\section{Procedure of the Research}

A questionnaire on the cultural competence of pre-service teachers was designed. It consisted of six sections: four of them are compliant with the four dimensions of the aforesaid model of cultural competence, one section deals with the respondents' evaluation of the opportunities to develop their cultural competence provided by the university they study at, and the last contains the respondents' demographical data. The paper versions of the questionnaire were distributed to pre-service teachers of foreign languages of five Lithuanian universities personally by the author of the article. Permissions to carry out the research were obtained from the administrative bodies of the faculties implementing the studies of foreign languages in all the universities.

\section{Research Findings}

\section{Knowledge and Awareness of Cultural Phenomena}

Culture is a very broad concept, so to get to know a given culture means to gain extensive knowledge and awareness of it. Hence, pursuing to explore the dimension of knowledge and awareness of cultural phenomena, four main forms of culture were distinguished: elite (or high culture/big C culture), ethnic (or folk/small-C culture), popular culture and subcultures.

Elite (high) culture is often attributed to aristocracy or upper social class, which is characterized as the ruling culture, which should be observed by everybody, or a privileged culture marked by peculiar spiritual, economic, political and other properties (Best, Lengyel \& Verzichelli, 2012). On the other hand, elite (or high) culture embraces world-famous and acknowledged works of art, as well as achievements in sports and science (Andrijauskas, 2006; Gaižutis, 2008; Lang \& Lang, 2009).

Ethnic (folk) culture, on the other hand, comprises a wide variety of aspects, many of which are inter-connected, including attitudes, assumptions, beliefs, perceptions, norms and values, social relationships, customs, celebrations, rituals, politeness conventions, patterns of interaction and discourse organization, the use of time in communication and other aspects characteristic of a particular nation or country. This form of culture embraces folk myths, rituals, customs, oral, musical and visual heritage, which are determined by common history, territory, race and language (Andrijauskas, 2006; Bukraba-Rylska, 2002; Fiske, 2008).

Popular culture is based on the stereotypes of mass consciousness, which seeks to imitate celebrities, satisfy hedonistic needs, conforms to the changing conditions and neglects own individuality and distinction. Consumer art, fashion, media and entertainment are attributed to this form of culture (Andrijauskas, 2006; Fiske, 2008).

The conception of contemporary culture is fragmented: the society breaks down into individual groups, which have peculiar culture, repudiate the prevailing norms and create alternative approaches to different aspects of life, including identity, religion, society and others. Subcultures involve independently functioning groups, which choose different stylistic forms to express their individuality and distinctness. They are often defined as either a highly educated part of society, which appears due to professional differentiation, or a completely uneducated marginal group (Andrijauskas, 2006; Ramanauskaitè, 2002).

Seeking to assess the first component of cultural competence, namely knowledge and awareness of cultural phenomena, pre-service teachers of foreign languages were provided with a list of the properties of culture forms and asked to attribute them to an appropriate form of culture. The frequency of the replies of the respondents is provided in Table 1.

Table 1. Attribution of the properties of culture forms by the respondents (\%)

\begin{tabular}{|l|l|l|l|l|l|l|l|l|}
\hline \multicolumn{1}{|l|}{ Culture form } & \multicolumn{2}{|l|}{ Elite culture } & \multicolumn{2}{l|}{ Ethnic culture } & \multicolumn{2}{l|}{ Popular culture } & \multicolumn{2}{l|}{ Subcultures } \\
\cline { 2 - 9 } & $\begin{array}{l}\text { Right } \\
\text { answers } \\
(\%)\end{array}$ & $\begin{array}{l}\text { Wrong } \\
\text { answers } \\
(\%)\end{array}$ & $\begin{array}{l}\text { Right } \\
\text { answers } \\
(\%)\end{array}$ & $\begin{array}{l}\text { Wrong } \\
\text { answers } \\
(\%)\end{array}$ & $\begin{array}{l}\text { Right } \\
\text { answers } \\
(\%)\end{array}$ & $\begin{array}{l}\text { Wrong } \\
\text { answers } \\
(\%)\end{array}$ & $\begin{array}{l}\text { Right } \\
\text { answers } \\
(\%)\end{array}$ & $\begin{array}{l}\text { Wrong } \\
\text { answers } \\
(\%)\end{array}$ \\
\hline Property 1 & 63.1 & 36.9 & 67.3 & 32.7 & 14.1 & 85.9 & 18.1 & 81.9 \\
\hline Property 2 & 37.1 & 62.9 & 81.0 & 19.0 & 67.7 & 32.3 & 68.8 & 31.2 \\
\hline
\end{tabular}




\begin{tabular}{|l|l|l|l|l|l|l|l|l|}
\hline Property 3 & 76.6 & 23.4 & 81.7 & 18.3 & 68.5 & 31.3 & 54.6 & 45.4 \\
\hline Property 4 & 89.1 & 10.9 & 89.7 & 10.3 & 56.7 & 43.3 & 62.7 & 37.3 \\
\hline Property 5 & 32.5 & 67.5 & 52.6 & 47.4 & 77.4 & 22.6 & 58.9 & 41.1 \\
\hline The mean: & 59.68 & 40.32 & 74.46 & 25.54 & 56.88 & 43.08 & 52.58 & 47.38 \\
\hline
\end{tabular}

The frequency analysis of pre-service teachers' knowledge and awareness of culture forms and their properties revealed that this dimension of cultural competence was rather mediocre. The knowledge about elite, popular and subcultures slightly surpassed $50 \%$ of attributing the outlined properties to an appropriate culture form, the least recognizable was subcultures $(52.58 \%)$. An exception was ethnic culture: the respondents managed to correctly attribute $74 \%$ of the outlined features.

Pre-service teachers of foreign languages were also asked to provide own examples illustrating the four culture forms as represented in own country and the country/countries of the studied foreign language. The replies were assessed with regard to the following criteria: 1 . The provided examples fully comply with the selected form of culture and represent the country; 2 . The provided examples comply with the form of culture but are not country-specific; 3 . The provided examples do not comply with the selected form of culture; and 4 . No examples are provided. The frequency of the choice of a culture form is presented in Table 2.

Table 2. Frequency of respondents' choice of a culture form

\begin{tabular}{|l|l|l|}
\hline Culture form & Frequency & Percent \\
\hline Elite culture & 89 & 17,7 \\
Ethnic culture & 94 & 18,7 \\
Popular culture & 189 & 37,5 \\
subcultures & 99 & 19,6 \\
No culture form & 33 & 6,5 \\
chosen & 504 & 100,0 \\
Total & & \\
\hline
\end{tabular}

The obtained results showed that the most frequent choice of pre-service teachers of foreign languages was popular culture $(37 \%)$. The frequency of the choice of the remaining three culture forms was relatively equal and ranged from about 18 to $20 \%$. Table 3 provides the data on the examples illustrating the selected culture form in the context of the native country of a respondent and in the context of the country of the target language. 
Table 3. Examples illustrating the selected culture form in the context of the ative and target country

\begin{tabular}{|c|c|c|c|c|}
\hline \multirow[b]{2}{*}{ Criterion } & \multicolumn{2}{|l|}{ Native } & \multicolumn{2}{|l|}{ Target } \\
\hline & Frequency & Percent & Frequency & Percent \\
\hline No examples are provided & 75 & 14.9 & 115 & 22,8 \\
\hline $\begin{array}{l}\text { The provided examples do not } \\
\text { comply with the selected form of } \\
\text { culture }\end{array}$ & 174 & 34.5 & 170 & 33,7 \\
\hline $\begin{array}{l}\text { The provided examples comply } \\
\text { with the form of culture but are not } \\
\text { country-specific }\end{array}$ & 154 & 30.6 & 134 & 26,6 \\
\hline $\begin{array}{l}\text { The provided examples fully } \\
\text { comply with the selected form of } \\
\text { culture and represent the country }\end{array}$ & 101 & 20,0 & 85 & 16,9 \\
\hline Total & 504 & 100,0 & 504 & \\
\hline
\end{tabular}

The obtained data demonstrated that the distribution of the results was similar in both contexts: representation of a culture form in the native country and the one of the target language. As it is seen from the table, only about $20 \%$ of preservice teachers of foreign languages provided examples that both complied with the form of culture and represented the selected culture in the context of the native country, whereas the results obtained in terms of the country of the target language were even lower ( 17\%). A third of future teachers showed good knowledge of culture forms; however, they were not able to attribute it to a specific context of a country (both native and that of the target language). Approximately the same percentage of students (slightly more than a third) showed no awareness of culture forms at all. Consequently, it is assumed that in general the knowledge and awareness of pre-service teachers of foreign languages was average: about a half of the respondents showed considerable understanding of culture forms, but only a small number $(\sim 17-20 \%)$ could illustrate it with country-specific examples.

\section{Emotional Attitude to Culture-specific Phenomena in the Country of Native and Target Language}

Knowledge and awareness of cultural phenomena is closely related to the second dimension of cultural competence, namely emotional attitude to cultural phenomena. It is assumed that emotions and feelings can either promote or suppress the acquisition of received information; thus, this dimension reveals the respondents' emotional attitude to a cultural phenomenon (DeCatanzano D. 2003). Pursuing to assess emotional perception of cultural phenomena, the pre-service teachers of foreign languages were given a list of seven emotions: pride, joy/admiration, concern, responsibility, anger/dissatisfaction, shame and guilt. According to Deardorff (2004) and Žemaitis (2005), these emotions are most frequently experienced with regard to own or target culture. The respondents were asked to define what cultural phenomena (objects, personalities, works of arts, literature, music, etc) raise the aforesaid emotions within the context of the native and target culture. Their replies were assessed in terms of the following criteria: 1 . Significant and countryspecific cultural phenomena are indicated; 2 . Significant aspects are indicated, but they do not relate to cultural phenomena; 3. Insignificant or trivial phenomena are indicated; and 4. No cultural phenomena are provided. The obtained results are presented in Table 4. 
Table 4. Emotional perception of cultural phenomena in the context of the native country (\%)

\begin{tabular}{|l|l|l|l|l|l|l|l|}
\hline \multicolumn{1}{|c|}{} & & & & & & & \\
\hline & & & & & & & \\
\hline
\end{tabular}

As it is seen from Table 4, the respondents managed to provide examples of significant and country specific phenomena when describing positive emotions, such as pride ( $\sim 65 \%$ with reference to the native country and $\sim 60 \%$ with reference to the target country) and joy or admiration ( $57 \%$ and $\sim 55 \%$ respectively). Among the provided phenomena most frequently mentioned were artists (musicians, painters, writers, etc) and their works, folklore, preservation of objects of cultural heritage, cultural education of children, preservation of language and its dialects, as well as different historical facts. About a quarter of pre-service teachers of foreign languages attributed their emotions of pride and joy/admiration ( $19 \%$ and $\sim 26 \%$ respectively) to different significant phenomena; however, these did not relate to a country-specific culture. They included different personal assumptions, like success of studies, consideration for family members, own health, friendship, protection of nature as well as different political and economic situations.

About a third of respondents felt concern about and responsibility for cultural phenomena pertaining to the native country or that of the target language. The future teachers were concerned about the growing emigration of Lithuanian youth to other European countries, which in their words, reduced the number of educated people in the country and weakened the nation itself. Speaking about their native country, the respondents felt responsible for the cultural education of children. Some of them were also worried about the spread of popular culture and the emergence of different subcultures, which incited the decline of the national and ethnic cultures. Another third of the respondents mentioned other significant aspects that did not relate to national culture: they were concerned about or felt responsible for their younger siblings and parents, studies, prospective career, protection of nature, etc. Unfortunately, over $40 \%$ of respondents indicated trivial or superficial aspects of their life.

As for the negative emotions, the respondents' replies split in a similar way: about a third of pre-service teachers experienced anger, shame and guilt regarding significant and culture-specific phenomena, such as intolerance to people of other cultures and beliefs, vandalism against objects of cultural heritage, violation of language norms using jargon, slang or borrowings from other languages, uneducated youth, and criminal behaviour of fellow-countrymen abroad, which 
diminished the status of the country on the international arena. Another third of the respondents specified different aspects unrelated to culture and over $30 \%$ of them provided insignificant and trivial ideas.

\section{Involvement in Cultural Activity}

The third dimension of cultural competence, involvement in cultural activity, demonstrates a person's capacity to perform specific actions in a certain culture-related situation. It was explored in terms of their capacity to perform culturally with regard to oneself and other people. A number of researchers (Lukšienè, 2000; Assagioli, 2000; Raven, 1999) maintain that cultural behaviour is manifested via a person's cultural intelligence. An intelligent person (homo intelligens) is well-read and highly educated, possesses substantial knowledge and demonstrates abilities of global thinking. Therefore, such a person takes keen interest in different fields of science, new ideas, arts, religion, philosophy, law, history and others. Another important feature is knowledge of the etiquette, which embraces well-mannered behaviour with others (speech, posture, politeness conventions, etc). Assagioli (2000) highlights the moral sense and personal responsibility of an intelligent person, which is manifested through such qualities as strong will, clear conscience, generosity, dignity and others. Moreover, a truly intelligent person shows extensive abilities of self-criticism and self-reflection.

The features of an intelligent person outlined in scientific literature were summarized in a description of an intelligent person, which embraces three aspects: intellect, etiquette and morality; and their empirical properties were identified. As a result, the respondents were provided with this description and asked to assess their achievements in each of the aforesaid aspects by indicating their capacity (I can't do it yet; I rarely do it; I sometimes do it; I can often do it). Their replies were measured in terms of four ranks: 1 . A student is able to mechanically perform certain activities; 2 . A student is able to establish positive relationships with others; 3 . A student is able to defend own position when interacting with others; and 4. A student reflects on own cultural expression, which is considered to show the highest level of a person's cultural intelligence. The obtained results are provided in Picture 1.

Picture 1. Pre-service teachers' assessment of own cultural intelligence

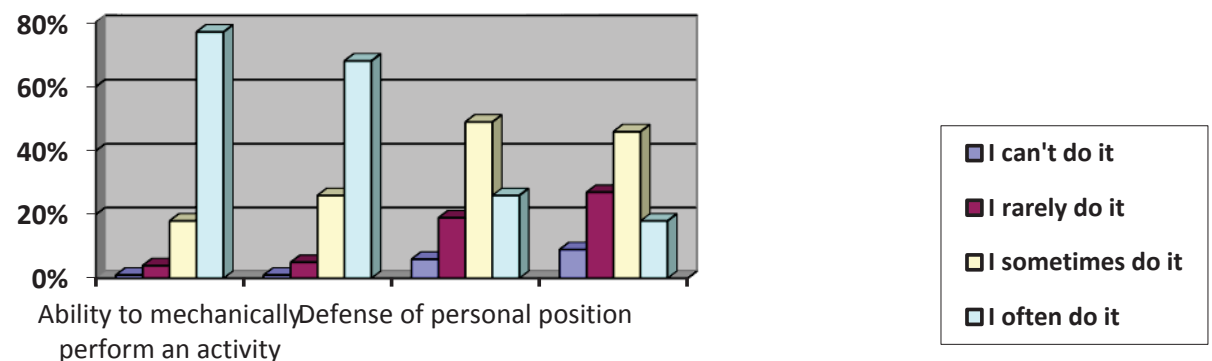

The obtained results demonstrate that as far as $79 \%$ of the respondents attributed most frequent occurrences of their cultural intelligence to mechanical performance of activities; whereas $68 \%$ maintained being able to frequently establish positive relationships with other people, and $26 \%$ stated that they sometimes established positive relationships with others. In terms of the ability to defend own position while interacting with other people, pre-service teachers of foreign languages appeared to be more self-critical: only about a quarter of the respondents $(26 \%)$ stated that they frequently defended their standpoint, and about a half of the respondents $(49 \%)$ declared being able to occasionally defend personal stand when communicating with others. Another quarter of pre-service teachers admitted that they rarely or never defended their position (19\% and $6 \%$ respectively). As far as pre-service teachers' reflection on own cultural expression is concerned, only $18 \%$ claimed doing it frequently, whereas less than a half of the respondents $(46 \%)$ stated that they reflected on their cultural expression occasionally. More than a quarter of pre-service teachers of foreign languages (27\%) pointed out that they rarely contemplated on their cultural expression, and $9 \%$ admitted never doing it. Consequently, it can be concluded that pre-service teachers evaluated their own cultural intelligence quite critically. It is noteworthy that there was a considerable regression in their ranking of own capacities: the higher the rank (considering mechanical accomplishment of 
activities as the lowest, and reflection on cultural expression as the highest rank), the less frequent capacities of the respondents were indicated.

\section{Cultural Literacy and Experience}

The last explored dimension of cultural competence of pre-service teachers of foreign languages was their cultural literacy and experience. It was explored as two-fold: firstly, it is assumed that experience acquired at different periods in life helps a person to develop and search for better decisions in other (similar or different) situations (Pukelis, 2009). Secondly, linguistic experience, i.e. acquired foreign language skills, ensure success of a person's performance in different intercultural environments.

To explore the first aspect of cultural experience and literacy, the respondents were given an open-ended question to describe the factors of former cultural activity, which they considered as having affected their further development and ability to perform in different cultural situations. The replies were summarized and attributed to the following sections: involvement in art activities (performing drama, painting, dancing, singing, writing literature, etc.); observation of arts (going to theatres, exhibitions, reading books, etc.); involvement in sports activities; travelling; meeting representatives of different cultures; art studies and other activities not related to culture. The obtained results are presented in Picture 2.

Picture 2. Cultural experience of pre-service teachers of foreign languages in terms of involvement in cultural activities

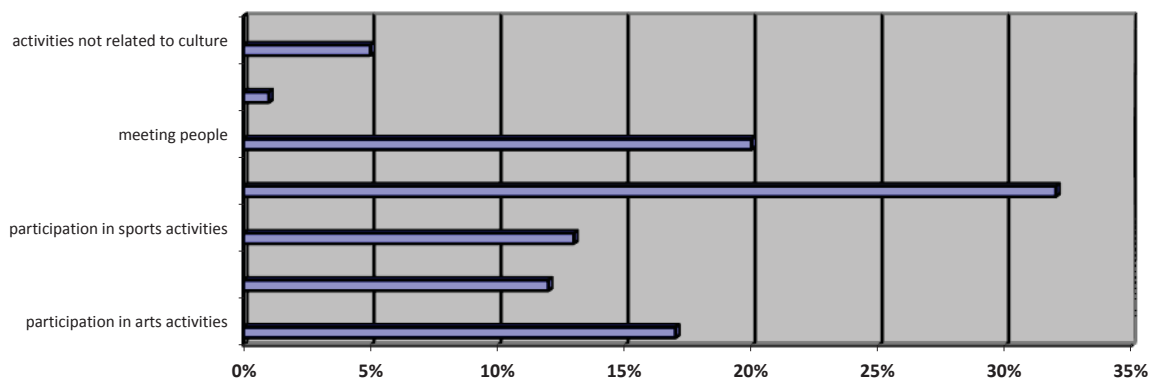

The obtained results revealed that pre-service teachers attached greatest importance to travelling $(32 \%)$ and meeting people of different cultures (20\%). Involvement in different art activities such as performing on stage, writing literature, etc. also received considerable percentage of the respondents' replies (17\%). The future teachers of foreign languages attributed less significance to observation of arts and involvement in sports activities (12\% and $13 \%$ respectively). When asked to validate their choices, the greater part of students emphasized the impact of cultural experience on their future development and ability to cope with various cultural situations; however, only $13 \%$ were able to specify it by describing specific situations or providing specific examples. Thus, it leads to a conclusion that pre-service teachers of foreign languages understood the role of gained cultural experience in their life and were able to identify which factors most significantly affected their further development as personalities. However, they were not yet capable of deeper analysis or reflection.

The second factor of pre-service teachers' cultural literacy and experience rests on foreign language skills. The respondents were offered descriptions of different communicative activities (listening, reading, speaking and writing) at different levels and asked to mark the section which best of all reflected their current level of foreign language skills. The descriptor was designed in accordance with the Common European Framework of Reference for Languages (2001). The distribution of the obtained results is presented in Picture 3. 
Picture 3. Distribution of the level of pre-service teachers' communicative skills
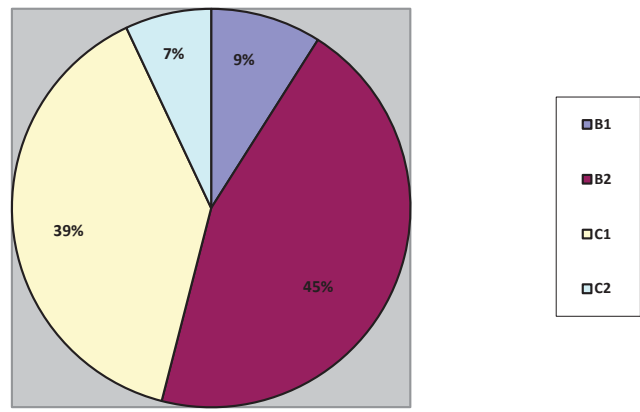

It is noteworthy that a greater part of the respondents attributed the current level of their communicative language skills to Levels B2 (45\%) or C1 (39\%). And only a considerably smaller number of pre-service teachers considered the level of their communicative language skills as either lower (B1) or higher (C2). No respondents, event first-year students, attributed their skills to level A1/A2. Consequently, it is assumed that the pre-service teachers of foreign languages adequately assessed their foreign language skills.

Pre-service teachers of foreign languages were also asked whether their foreign language skills sufficed communication with representatives of foreign countries. They were asked to assess their skills of interacting in a foreign language as highly sufficient, sufficient, average and lower than average. Their answers are summarized in Picture 4.

Picture 4. Assessment of the sufficiency of foreign language skills of pre-service teachers of foreign languages

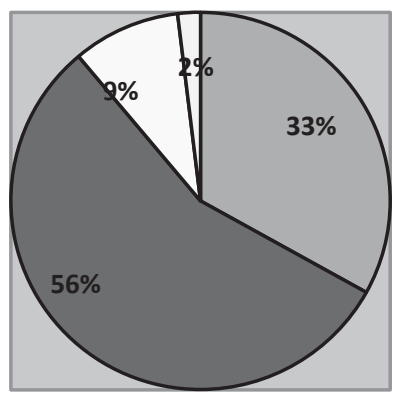

\begin{tabular}{|l|}
\hline highly sufficient \\
$\square$ sufficient \\
$\square$ average \\
$\square$ insufficient \\
\hline
\end{tabular}

As it is seen from the picture, more than a half of the respondents considered that their foreign language skills were sufficient and a third more believed that they had highly sufficient skills. And only a tenth of pre-service teachers assumed that their foreign language skills were average or insufficient. Consequently, it can be concluded that pre-service teachers of foreign languages did not experience much difficulty while interacting with representatives of different cultures.

\section{Contribution of University Studies of a Foreign Language to the Development of Pre-service Teachers' Cultural Competence}

As far as their culture studies at university were concerned, $67 \%$ of pre-service stated that they obtained highly sufficient or sufficient knowledge and skills of the cultural aspect of the target language; $6 \%$ of the respondents expressed no opinion, whereas $27 \%$ of students claimed that they acquired no knowledge or skills, which might be of use for their cultural 
development. $71 \%$ of the respondents, who claimed obtaining sufficient knowledge and skills of cultural competence, maintained that they acquired cultural knowledge mostly from the courses of Country Studies/History of the Country, Thematic Development/Vocabulary Studies, and $24 \%$ added Literary Text Analysis/Literature Studies. Nevertheless, they expected more practical teaching, which would involve communication with visiting teachers, preferably native-speakers $(65 \%)$, more students coming on exchange programmes (19\%), as well as more opportunities to go to universities of the countries of the target language (28\%). $73 \%$ of pre-service teachers of foreign languages would appreciate more diverse activities integrating cultural aspects into language studies: cultural events and performances, watching and discussing films and videos, organizing virtual tours to other countries, organizing simulation trips to Lithuania for foreign guests and other activities.

\section{Conclusions}

The results of the research revealed that the first dimension of pre-service teachers' cultural competence, knowledge and awareness of the forms of culture is rather mediocre. The respondents managed to attribute as far as $50 \%$ of the outlined features to an appropriate culture form. An exception was ethnic (folk) culture, where they recognized $74 \%$ of the outlined properties. Only a fifth of future teachers of foreign languages could substantiate their understanding of culture forms by providing country-specific examples of cultural phenomena; whereas about a third of research participants showed the ability to provide examples compliant to individual culture forms, though could not relate them to a country-specific context.

The analysis of the research results of emotional attitude to cultural phenomena shows that pre-service teachers of foreign languages largely attribute their emotional perceptions to different personal assumptions, as well as economical, political, environmental and other aspects rather than cultural phenomena. Only about a third of the respondents were able to define their emotions with regard to cultural phenomena, which included artists and their works, preservation of objects of cultural inheritance, cultural education of children, etc. An exception was observed while analyzing the data pertaining to the pre-service teachers' pride and admiration/joy: more than a half of the respondents managed to relate these emotions to significant country-specific phenomena.

As far as pre-service teachers' involvement in cultural activity is concerned, the analysis of the research data revealed that the respondents positioned own capacities rather high: around three quarters of the respondents attributed most frequent occurrences of their cultural behaviour to mechanical performance of activities and establishment of positive relationships with others. In terms of the ability to defend own position interacting with other people, the respondents turned out to be more self-critical: only about a quarter of the respondents stated that they frequently defended their personal position, and about a half of them maintained being able to occasionally do it when communicating with others. It seems that pre-service teachers of foreign languages tend to demonstrate a rather mechanical behaviour in different cultural contexts devoid of deeper analysis or reflection.

The last dimension of cultural competence, cultural literacy and experience, was revealed as two-fold: cultural experience acquired at different periods in life and the acquired foreign language skills, which presumably affect the respondents' capacity to perform in different cultural and intercultural contexts. It appeared that about a half of the respondents attached greatest significance to such factors as travelling and meeting people of different cultures as the most decisive in developing their cultural experience and ability to cope with various (inter)cultural situations. However, only $13 \%$ were able to precisely specify the impact of the mentioned factors by giving concrete examples or situations. A majority of respondents attached the current level of their foreign language skills to Levels B2 or C1 and considered them as highly sufficient or sufficient to interact with representatives of different cultures. It is assumed that the pre-service teachers of foreign languages adequately assessed their foreign language skills by stating that they did not experience much difficulty while interacting in different cultural contexts.

Having summarized and considered the results of the study, it appeared that pre-service teachers of foreign languages were eager to enrich their awareness of other cultures while learning a foreign language. In addition, they appreciated interacting with people from different cultural backgrounds, respected their values and wanted to learn how to communicate with them. The respondents' evaluation of the development of their cultural competence at university is rather positive. However, more diverse activities should be offered as well as more opportunities to interact with native speakers should be provided to pre-service teachers. 


\section{References}

Andrijauskas A. (2006). Technogeninè civilizacija, medijos ir kultūros globalizacija. In: Kultūrologija 13. Kultūra globalizacijos salygomis. Vilnius: Kultūros, filosofijos ir meno institutas, p. 76-96.

Assagioli R. (2000). Psychosynthesis: a collection of basic writings. Synthesis Center Inc.

Bauman Z. (2007). Globalizacija: pasekmès žmogui. Vilnius: Apostrofa.

Best H., Lengyel G. \& Verzichelli L. (ed.) (2012). The Europe of Elites: a Study into the Europeanness of Europe's Political and Economic Elites. Oxford, New York: Oxford University Press.

Byram, M., Gribkova, B., Starkey, H. (2002). Developing the intercultural dimension in language teaching: a practical introduction for teachers. Strasbourg: the Council of Europe.

Byram, M., Morgan, C. at al. (1994). Teaching and learning language and culture. Great Britain: WBC.

Bukraba-Rylska I. (2002). Kultura ludowa w społeczeństwie współczesnym. In: Kultura ludowa, wieś, mieszkańcy wsi : wybór artykułów z lat 1987-2002, Warszawa: Instytut Rozwoju Wsi i Rolnictwa Polskiej Akademii Nauk.

Common European framework of reference for languages: learning, teaching, sssessment, (2001). Retrieved 25 April 2014 from: http://www.coe.int///dg4/linguistic/Source/ Framework_en.pdf

Deardorff D. K. (2004). The identification and assessment of intercultural competence as a student outcome of internationalization at institutions of higher education in the United States: doctoral dissertation. Raleigh: North Carolina.

DeCatanzano D. 2003. Motywacje i emocje. Poznan: Zysk I S-ka Wydawnictwo.

Fiske J. (2008). Populiariosios kultūros supratimas. Vilnius: Žara.

Gaižutis A. (2008). Daugiaveidis elitas. Vilnius: Vilniaus pedagoginio universiteto leidykla.

Genc, B. \& Bada, E. (2005). Culture in language learning and teaching. In: The Reading Matrix, Vol. 5, No. 1, p. 73-84.

Kramsch, C. (2000). Language and culture. Oxford: Oxford University Press.

Lang K. \& Lang G. E. (2009). Mass society, mass culture and mass communication: the meaning of mass. In: International Journal of Communication, No. 3, p. 998-1024.

Lietuvos Respublikos švietimo istatymas (Law on Education of the Republic of Lithuania). Passed on 17 March 2011, No. XI- 1281. Retrieved 25 April 2014 from: http://www3.Irs.It.

Lukšienė M. (2000). Jungtys. Vilnius: Alma Littera.

Mokytoju profesijos kompetencijos aprašas (National Description of Teacher Competences) (2007). Retrieved 24 April 2014 from: http://www3.Irs.It/pls/inter3/dokpaieska.showdoc_p?p_id=291726 .

Pegrum M. (2008). Film, culture and identity: critical intercultural literacies for the language classroom. In: Language and Intercultural Communication, V. 8, No. 2, p. 136-154.

Qu, Y. (2010). Culture understanding in foreign language teaching. In: English Language Teaching, Vol. 3, No. 4, December 2010, p. 58-61.

Ramanauskaitė E. (2002). Šiuolaikinės kultūros fenomenu tyrinëjimai. Kaunas: Vytauto Didžiojo universiteto leidykla.

Raven J. (2001) Competence in the learning society. Peter Lang International Academic Publishers.

Recommendation of the European Parliament and of the Council on Key Competences for Life-long Learning (2006). Retrieved 24 April 2014 from: http://eur-lex.europa.eu/LexUriServ/LexUriServ.do?uri=OJ:L:2006:394:0010:0018:en:PDF.

Savignon, S. J. (2002). Interpreting communicative language teaching: contexts and concerns in teacher education. New Haven and London: Yale Univcersity Press.

Žemaitis V. (2005). Etikos žodynas. Vilnius: Rosma. 